\title{
Seasonal Variation of the Microbial Quality of Local Vegetables in Giresun, the Northern Province of Turkey
}

\author{
Atnan Uğur ${ }^{1, a, *}$, Hilal Yıldız ${ }^{2, b}$, Olcay Kavgaci ${ }^{3, c}$ \\ ${ }^{1}$ Department of Horticulture, Faculty of Agriculture, Ordu University, 52200 Ordu, Turkey. \\ ${ }^{2}$ Department of Food Engineering, Faculty of Engineering and Architecture, Nevşehir Haci Bektaş University, 50300 Nevşehir, Turkey. \\ ${ }^{3}$ Provincal Food Control Directorate, 28100 Giresun, Turkey. \\ *Corresponding author
}

A R T I C L I N F O A B S T R A C T

Research Article

Consumption of vegetables, having a significant place in nutrition of humankind, is increasing day by day as their health-improving effects have been better understood nowadays. The main threat to food safety is pathogenic bacteria that cause several foodborne outbreaks. The microbial quality of vegetables are affected by certain criteria such as organic production, season production, regional production. The objective of this study is to examine the presence of Bacillus cereus and Salmonella

Received : 23/09/2021

Accepted : 05/11/2021 spp. in the vegetables sold in markets grown locally in different seasons. The 89 samples, including parsley, lettuce, spinach, turnip, carrot, chard, Brussels sprouts and radish produced in the province of Giresun were analyzed in the study. The presence of Bacillus cereus and Salmonella spp. was determined according to the International Organization for Standardization procedure. Salmonella spp. was not determined in any of the analysed samples. On the other hand, B. cereus was detected

Keywords:

Consume

Contamination in 84 samples with microbial load ranging between $1.0 \times 10^{2}$ and $4.9 \times 10^{4} \mathrm{CFU} / \mathrm{g}$. Among the samples, the highest B. cereus contamination was observed in lettuce with a $3.1 \times 10^{3} \mathrm{CFU} / \mathrm{g}$. The results showed that $B$. cereus counts varied by seasons, and the highest count was obtained from Health the samples grown in spring seasons. Determination of the sources of contamination for the vegetables in pre-harvesting and post-harvesting periods, provides information about the condition of production. The results will help raise the awareness of the farmers about the contamination risks from production to marketing for the prevention of microbial contamination.

\section{Introduction}

Vegetables are plants of which different parts such as roots, stems, leaves, bears, flowers, seeds and shoots have been consumed since the early ages. In time, many of them were cultivated depending on needs and consumption. Though different factors affect vegetable consumption, vegetable production and consumption cultures have developed based on ecologies (Ugur et al., 2014). Nowadays, the main goal of vegetable consumption is to satisfy the need for carbohydrates, vitamins and minerals of humans. In addition to their essential nutrients, increasing and popularizing consumption of vegetables are considered to be a viable strategy due to their mineral and secondary metabolite content (Barminas et al., 1998; Sevindik et al., 2017; Pehlivan et al., 2021). Pulses, thanks to their high protein content, are included in diets due to the limited means of access to meat and meat products (Pekşen and Artık, 2005). Fresh vegetables are rich in both water-soluble vitamins and other nutrients required for improving nutritional status and reducing the risk of cardiovascular diseases (Alissa and Ferns, 2017). Moreover, it is stated that fresh vegetables are effective for prevention of many chronic diseases and ailments thanks to their rich content of polyphenols, carotenoids, alkaloids, flavonoids, secondary metabolites and antioxidants (Steinmetz and Potter, 1996; Baslam et al., 2011; Mohammed et al., 2020). It is observed that many diseases and outbreaks occur in regions with limited vegetable consumption because of malnutrition and unhygienic living conditions (Ignarro et al., 2007; Ronto et al., 2018).

Various economic, sociological and ecological factors are influential on vegetable consumption (Ugur et al., 2014). Despite ecological factors' drawing interest as the most effectual ones, we find different forms of vegetable consumption in different societies due to cultural factors. On the other hand, socioeconomic factors affect the type and quantity of the vegetables consumes. As low-income 
families generally consume vegetables for their needs of nutrition/energy, potato consumption is more common in such families. In high income families, vegetables are considered as means of diversifying the diet and supermarkets and greengrocers are preferred despite selling vegetables for higher prices (Ugur et al., 2014). As the level of awareness and income of societies has increased, vegetable consumption has been regarded as a way of healthy nutrition instead of an activity for putting on the feed bag and nutritional and bioactive agent contents of the vegetables have been started to be taken into consideration (Baslam et al., 2011; Yen and Tan, 2012). Furthermore, factors such as organic production, season production, being hormone-free, being locally-grown products and packaging/labelling have gained significance while assessing the production and marketing process of the vegetables (Mie et al., 2017). Locally-grown products have been preferred for reasons such as compatible with traditional appetite, freshness and non-use/limited use of synthetic inputs (Avgoustaki and Xydis, 2020). However, use of animal manure instead of chemical fertilizers in local vegetable growing and the possibility of use of pathogenic water mixed with sewage water may pose a risk in terms of safety of such products (Beuchat and Ryu, 1997). Pathogenic bacteria in both the natural flora of the soil and intestinal system of humans and animals such as Clostridium botulinum, B. cereus, Listeria monocytogenes and Salmonella spp., Shigella spp., E. coli, Campylobacter spp. as well as parasites may contaminate the raw vegetables (Bergwerff and Debast, 2021). In raw products, contamination with such pathogenic microorganisms may occur throughout the entire food transport and processing procedure from the farm up until the consumption (Zhao et al., 2009). Microbial contamination may also arise during the processing and packing procedures following the harvesting. Moreover, the raw vegetables may be exposed to pathogenic contamination when not cooked carefully and may be hazardous to human healthy especially when they are consumed raw (Balali et al., 2020). Therefore, food safety is sought for the products consumed and it is expected to minimize the possible dangers and risks associated with the raw vegetables from their harvesting till their consumption by the end user within the frame of the applicable legislations and standard measures determined by the authorities (Gil et al., 2015). It is aimed to bring the infections related with food to a level that will not harm the public health and/or totally eliminate such infections (Giray and Soysal, 2007). Salmonella spp. and $B$. cereus are significant bacteria that may be infected with food and endanger public health. Salmonella spp. are moving, asporous, unencapsulated gram negative bacteria in the form of basil. Salmonella spp. may colonize in gastrointestinal system of numerous animals including all mammals, birds and insects (D'aoust and Maurer, 2007). Salmonella spp. may reproduce greatly in 24 hours under a temperature of $37^{\circ} \mathrm{C}$. They can live for a long time in humid environments out of sunlight, sewage water, well water and soil. Infection generally happens by consuming the water and food infected by these bacteria. Salmonella infections occur through oral rote with contaminated food and water (Kenney, 2019). Being protected from Salmonella requires caring for personal hygiene rules, consuming clean water and food, eradicating the carriers and installing proper sewage system (Yücel, 2020).

$B$. cereus is a food-originated pathogen generally contaminating the vegetative food (Valero et al., 2003). $B$. cereus can be found in naturally-decomposing organic matters, fresh water and sea water, vegetables and intestinal flora of different animals. Due to viscid nature of endospores, B. cereus may hold on to food production environments frequently. It can infect different types of food such milk and diary, vegetables, rice and rice food, meat and meat products, soups and spices (Kumari and Sarkar, 2016; Organji et al., 2015). Food poisoning associated with $B$. cereus may be observed throughout the whole globe in any season. Its prevalence is closely associated with preparing and storing food under improper conditions. Consumption of food containing $10^{6} \mathrm{CFU} B$. cereus per gram is sufficient for development of clinical picture. B. cereus produces toxins in the body upon consumption of infected food and may lead to two gastrointestinal diseases namely emetic (vomiting) and diarrhea (Kim et al., 2010). When emetic toxin (cereulide) is produced in food, the infected person vomits after swallowing the contaminated food. Diarrhea syndrome arises when enterotoxins are produced in bowels following swallowing of food contaminated with B. cereus (Kumari and Sarkar, 2016). And this threatens the human life. The objective of this study is to identify the microbial contamination in the vegetables grown in the province of Giresun, the Northern Province of Turkey, and offered in local bazaars by the farmers.

\section{Materials and Methods}

\section{Research Area}

The research area lies between $37^{\circ} 50^{\prime}-39^{\circ} 12^{\prime}$ east longitudes and $40^{\circ} 07^{\prime}-41^{\circ} 08^{\prime}$ north latitudes in the province of Giresun. The coastal region of the province is formed of high-slope valleys split by streams. The settlement is dense on the small planes at the mouths of the streams. Population density is lower in mountainous areas and the population mostly deals with plant growing and livestock. Hazelnut is the most significant agricultural product and vegetables are grown on small yards with traditional methods by using local seeds to contribute in household economy. Such vegetables grown by women are also offered by them in local bazaars. Use of animal manure is common for vegetable growing and open system irrigation (surface irrigation) is preferred. There is no sewage system in mountainous areas.

\section{Material}

Total 89 vegetable samples grown in the province of Giresun and offered in local bazaars [parsley (28), lettuce (38), spinach (11), turnip (4), carrot (2), chard (2) radish (2) and Brussels sprouts (2)] form the main material of the research. No sampling was performed for the vegetables. Samples were taken from the vegetables offered in local bazaars in every season in every fifteen days. The samples were kept at $0-5^{\circ} \mathrm{C}$ and analyzed in 24 hours. In the samples of parsley, lettuce and spinach, bacteria were detected in autumn, winter and spring but they were only detected in autumn for the samples of turnip, radish, carrot, Brussels sprouts and chard. 


\section{Methods}

To determine the microbial load in vegetable samples, Salmonella spp. and Bacillus cereus bacteria were detected.

\section{Detection of Salmonella spp. in Vegetables}

$25 \mathrm{~g}$ of vegetable samples were homogenized with Buffered peptone water $(225 \mathrm{~mL})$ under aseptic conditions and then incubated for $18 \pm 2$ hours at $37 \pm 1^{\circ} \mathrm{C}$. After incubation, $1 \mathrm{~mL}$ of pre-enriched samples was added into the tubes containing $10 \mathrm{ml}$ Rapaport Vassililadis Soy Medium (RVS) and incubated for $24 \pm 3$ hours at $41.5 \pm 1^{\circ} \mathrm{C}$ $10 \mathrm{~mL}$ of pre-enriched samples were added into the bottles containing $100 \mathrm{~mL}$ of Muller-Kauffmanbroth Novobiocin Broth (MKTTn) and the bottles were incubated for $24 \pm 3$ hours at $37 \pm 1^{\circ} \mathrm{C}$. and for $24 \pm 3$ hours at $37 \pm 1^{\circ} \mathrm{C}$. Following the incubation, a streaking loop was dipped into the mediums of RVS and MKTTn separately and used to streak onto Xylose-Lysine-Desoxycholate Agar (XLD agar) and Chromegenic Salmonella agar plates. The plates were incubated for $24 \pm 3$ hours at $37 \pm 1^{\circ} \mathrm{C}$. The typical colonies grown on XLD agar and Chromegenic Salmonella agar were picked up and inoculated on Blood agar and Nutrient agar. Typical colonies of Chromegenic Salmonella agar were purple - dark pink, $1 \mathrm{~mm}$ and smooth and colonies of XLD agar had a black center and slightly transparent reddish zones due to colour change of the indicator. Then, petri dishes incubated for $24 \pm 3$ hours at
$37 \pm 1^{\circ} \mathrm{C}$. Following the incubation, the colonies multiplied on Blood agar and XLD agar were verified by gram negative kits of Vitek 2 system (National Standards Authority of Turkey, 2020).

\section{Detection of Bacillus cereus in Vegetables}

$10 \mathrm{~g}$ of samples were taken from the vegetables under aseptic environment and transferred to stomacher bags containing $90 \mathrm{ml}$ Maximum Recovery Diluent (MRD) and homogenized. A serial ten-fold-dilution was performed by pipetting. $0.1 \mathrm{~mL}$ was taken from the appropriate dilutions and inoculated on chromogenic agar (Bacara) using the surface spreading method. The plates were incubated for $22 \pm 2$ hours at $30 \pm{ }^{\circ} \mathrm{C}$ and the orange colonies and those with surrounding white zones were counted (National Standards Authority of Turkey, 2009).

\section{Analysis of the Data}

No advanced statistics were used in the study, only the arithmetic mean of the samples according to the harvest season of the vegetables was taken. The measurements were taken using the spectroradiometer.

\section{Results}

In the study, we examined presence of Bacillus cereus and Salmonella spp. in 89 vegetable samples grown by the female farmers in autumn, winter and spring.

Table 1. Existence of Bacillus cereus in parsley

\begin{tabular}{|c|c|c|}
\hline Harvest season & Sample no & Bacillus cereus (CFU/g) \\
\hline \multirow{2}{*}{ Autum } & Sample 1 & $1.0 \times 10^{2}$ \\
\hline & Autum mean & $1.0 \times 10^{2}$ \\
\hline \multirow{12}{*}{ Winter } & Sample 1 & $<10$ \\
\hline & Sample 2 & $1.0 \times 10^{2}$ \\
\hline & Sample 3 & $1.0 \times 10^{3}$ \\
\hline & Sample 4 & $3.0 \times 10^{2}$ \\
\hline & Sample 5 & $1.0 \times 10^{2}$ \\
\hline & Sample 6 & $1.3 \times 10^{3}$ \\
\hline & Sample 7 & $5.0 \times 10^{2}$ \\
\hline & Sample 8 & $1.0 \times 10^{2}$ \\
\hline & Sample 9 & $4.0 \times 10^{2}$ \\
\hline & Sample 10 & $<10$ \\
\hline & Sample 11 & $4.0 \times 10^{2}$ \\
\hline & Winter mean & $3.5 \times 10^{2}$ \\
\hline \multirow{17}{*}{ Spring } & Sample 1 & $2.0 \times 10^{2}$ \\
\hline & Sample 2 & $1.6 \times 10^{3}$ \\
\hline & Sample 3 & $7.0 \times 10^{2}$ \\
\hline & Sample 4 & $1.0 \times 10^{2}$ \\
\hline & Sample 5 & $7.0 \times 10^{2}$ \\
\hline & Sample 6 & $2.0 \times 10^{2}$ \\
\hline & Sample 7 & $9.0 \times 10^{2}$ \\
\hline & Sample 8 & $1.0 \times 10^{2}$ \\
\hline & Sample 9 & $<10$ \\
\hline & Sample 10 & $<10$ \\
\hline & Sample 11 & $5.0 \times 10^{2}$ \\
\hline & Sample 12 & $2.0 \times 10^{2}$ \\
\hline & Sample 13 & $7.0 \times 10^{1}$ \\
\hline & Sample 14 & $6.0 \times 10^{1}$ \\
\hline & Sample 15 & $3.0 \times 10^{3}$ \\
\hline & Sample 16 & $2.0 \times 10^{2}$ \\
\hline & Spring mean & $5.3 \times 10^{2}$ \\
\hline General Mean & & $4.6 \times 10^{2}$ \\
\hline
\end{tabular}


Table 2. Existence of Bacillus cereus in lettuce

\begin{tabular}{|c|c|c|}
\hline Harvest season & Sample no & Bacillus cereus $(\mathrm{CFU} / \mathrm{g})$ \\
\hline \multirow{7}{*}{ Autum } & Sample 1 & $8.0 \times 10^{2}$ \\
\hline & Sample 2 & $4.0 \times 10^{2}$ \\
\hline & Sample 3 & $7.0 \times 10^{2}$ \\
\hline & Sample 4 & $1.4 \times 10^{3}$ \\
\hline & Sample 5 & $1.4 \times 10^{3}$ \\
\hline & Sample 6 & $2.0 \times 10^{2}$ \\
\hline & Autum mean & $8.2 \times 10^{2}$ \\
\hline \multirow{17}{*}{ Winter } & Sample 1 & $6.0 \times 10^{2}$ \\
\hline & Sample 2 & $7.0 \times 10^{2}$ \\
\hline & Sample 3 & $4.0 \times 10^{3}$ \\
\hline & Sample 4 & $2.3 \times 10^{3}$ \\
\hline & Sample 5 & $9.0 \times 10^{2}$ \\
\hline & Sample 6 & $1.2 \times 10^{3}$ \\
\hline & Sample 7 & $7.0 \times 10^{2}$ \\
\hline & Sample 8 & $2.8 \times 10^{3}$ \\
\hline & Sample 9 & $4.0 \times 10^{2}$ \\
\hline & Sample 10 & $4.0 \times 10^{2}$ \\
\hline & Sample 11 & $4.8 \times 10^{3}$ \\
\hline & Sample 12 & $9.0 \times 10^{2}$ \\
\hline & Sample 13 & $1.5 \times 10^{3}$ \\
\hline & Sample 14 & $1.7 \times 10^{3}$ \\
\hline & Sample 15 & $6.0 \times 10^{2}$ \\
\hline & Sample 16 & $6.0 \times 10^{2}$ \\
\hline & Winter mean & $1.5 \times 10^{3}$ \\
\hline \multirow{17}{*}{ Spring } & Sample 1 & $1.9 \times 10^{3}$ \\
\hline & Sample 2 & $2.7 \times 10^{3}$ \\
\hline & Sample 3 & $4.7 \times 10^{3}$ \\
\hline & Sample 4 & $1.2 \times 10^{3}$ \\
\hline & Sample 5 & $9.0 \times 10^{2}$ \\
\hline & Sample 6 & $4.0 \times 10^{2}$ \\
\hline & Sample 7 & $<10$ \\
\hline & Sample 8 & $1.2 \times 10^{3}$ \\
\hline & Sample 9 & $1.1 \times 10^{3}$ \\
\hline & Sample 10 & $4.0 \times 10^{2}$ \\
\hline & Sample 11 & $4.0 \times 10^{2}$ \\
\hline & Sample 12 & $1.2 \times 10^{3}$ \\
\hline & Sample 13 & $1.7 \times 10^{4}$ \\
\hline & Sample 14 & $1.9 \times 10^{3}$ \\
\hline & Sample 15 & $6.0 \times 10^{3}$ \\
\hline & Sample 16 & $4.9 \times 10^{4}$ \\
\hline & Spring mean & $5.6 \times 10^{3}$ \\
\hline General mean & & $3.1 \times 10^{3}$ \\
\hline
\end{tabular}

Table 3. Existence of Bacillus cereus in spinach

\begin{tabular}{l|cc}
\hline Harvest season & Sample no & Bacillus cereus $($ CFU/g) \\
\hline \multirow{4}{*}{ Autum } & Sample 1 & $9.0 \times 10^{2}$ \\
& Sample 2 & $1.0 \times 10^{2}$ \\
& Sample 3 & $1.0 \times 10^{2}$ \\
& Autum mean & $3.7 \times 10^{2}$ \\
\hline \multirow{3}{*}{ Winter } & Sample 1 & $7.0 \times 10^{2}$ \\
& Sample 2 & $2.0 \times 10^{2}$ \\
& Sample 3 & $4.0 \times 10^{2}$ \\
& Sample 4 & $3.4 \times 10^{2}$ \\
& Sample 5 & $3.0 \times 10^{2}$ \\
Spring & Winter mean & $3.9 \times 10^{2}$ \\
& Sample 1 & $3.0 \times 10^{2}$ \\
& Sample 2 & $1.2 \times 10^{3}$ \\
General mean & Sample 3 & $4.3 \times 10^{2}$ \\
\hline
\end{tabular}


Table 4. Bacillus cereus numbers in parsley, lettuce and spinach by seasons

\begin{tabular}{l|ccc}
\hline Harvest season & Minimum values $(\mathrm{CFU} / \mathrm{g})$ & Maximum values(CFU/g) & Mean values(CFU/g) \\
\hline Autum & $1.0 \times 10^{2}$ & $1.4 \times 10^{2}$ & $6.1 \times 10^{2}$ \\
Winter & $<10$ & $4.8 \times 10^{3}$ & $9.5 \times 10^{2}$ \\
Spring & $<10$ & $4.9 \times 10^{4}$ & $2.9 \times 10^{3}$ \\
\hline
\end{tabular}

Table 5. Existence of Bacillus cereus in turnip, radish, carrot, brussels sprouts and chard

\begin{tabular}{c|cc}
\hline & Sample no & Bacillus cereus $(\mathrm{CFU} / \mathrm{g})$ \\
\hline \multirow{4}{*}{ Turnip } & Sample 1 & $3.0 \times 10^{2}$ \\
& Sample 2 & $5.0 \times 10^{2}$ \\
& Sample 3 & $4.2 \times 10^{2}$ \\
& Sample 4 & $7.0 \times 10^{2}$ \\
& Mean & $4.8 \times 10^{2}$ \\
\hline \multirow{2}{*}{ Radish } & Sample 1 & $4.0 \times 10^{2}$ \\
& Sample 2 & $4.0 \times 10^{2}$ \\
& Mean & $4.0 \times 10^{2}$ \\
\hline \multirow{2}{*}{ Carrot } & Sample 1 & $5.2 \times 10^{2}$ \\
& Sample 2 & $4.3 \times 10^{2}$ \\
& Mean & $4.8 \times 10^{2}$ \\
\hline \multirow{2}{*}{ Brussels sprout } & Sample 1 & $4.0 \times 10^{2}$ \\
& Sample 2 & $2.0 \times 10^{2}$ \\
& Mean & $3.0 \times 10^{2}$ \\
\hline \multirow{2}{*}{ Chard } & Sample 1 & $2.0 \times 10^{2}$ \\
& Sample 2 & $3.2 \times 10^{2}$ \\
& Mean & $2.6 \times 10^{2}$ \\
\hline
\end{tabular}

\section{Existence of Bacillus cereus in Vegetables}

Existence of Bacillus cereus in Parsley

The data regarding detection of Bacillus cereus in parsley were given in the Table 1. In two parsley samples, B. cereus could not be detected in winter and spring. In autumn, $1.0 \times 102 \mathrm{CFU} / \mathrm{g}$ bacteria were detected in only one sample. The highest bacteria level was measured to be $1.3 \times 10^{3} \mathrm{CFU} / \mathrm{g}$ and $3.0 \times 10^{3} \mathrm{CFU} / \mathrm{g}$ for the parsleys of winter and spring respectively. Considering existence of Bacillus cereus in parsley, the ranking was as following: autumn<winter<spring. B. cereus number detected in parsley is $4.4 \times 10^{2} \mathrm{CFU} / \mathrm{g}$ adjusting by average of all samples (Table 1).

Existence of Bacillus cereus in Lettuce

The data regarding detection of $B$. cereus in lettuce were given in the Table 2 . B. cereus numbers varying in between $4.0 \times 10^{2}$ and $4.9 \times 10^{4}$ was detected in all lettuce samples except for the one taken in spring. B. cereus ranking by seasons was as following: autumn<winter<spring. The highest bacteria level was measured to be $5.6 \times 10^{3} \mathrm{CFU} / \mathrm{g}$ for the lettuce samples of spring. Average B. cereus number of lettuce samples were calculated to be $3.1 \times 10^{3} \mathrm{CFU} / \mathrm{g}$ (Table 2).

Existence of Bacillus cereus in Spinach

The data regarding detection of $B$. cereus in spinach were given in the Table 3. B. cereus numbers in spinach varied in between $1.0 \times 10^{2}$ and $1.2 \times 10^{3} \mathrm{CFU} / \mathrm{g}$ by seasons. The lowest $B$. cereus number of $3.7 \times 10^{2} \mathrm{CFU} / \mathrm{g}$ was detected in autumn and the highest level of $6.4 \times 10^{2} \mathrm{CFU} / \mathrm{g}$ was detected in spring according to average values. The highest value in the spinach samples in terms of B. cereus number was $1.2 \times 10^{3}$ and it was detected in spring (Table $3)$.
Existence of Bacillus cereus in Parsley, Lettuce and Spinach by Seasons

Minimum, maximum and average $B$. cereus numbers detected in the samples of parsley, lettuce and spinach by seasons were given in the Table 4. B. cereus numbers varied by seasons. While the highest bacteria number of $2.9 \times 10^{3} \mathrm{CFU} / \mathrm{g}$ was detected in spring, the lowest figure of $6.1 \times 10^{2} \mathrm{CFU} / \mathrm{g}$ was detected in autumn (Table 4).

Existence of Bacillus cereus in Turnip, Radish, Carrot, Brussels Sprouts and Chard

Sampling was only performed in autumn for Turnip, Radish, Carrot, Sprouts and Chard and the B. cereus numbers in these samples were given in the Table 5. It was identified that the $B$. cereus number in turnip, radish, carrot, brussels sprouts and chard was $2.0 \times 10^{2}-7.0 \times 10^{2}$ $\mathrm{CFU} / \mathrm{g}$ in autumn. Turnip and carrot yielded the similar values of $4.8 \times 10^{2} \mathrm{CFU} / \mathrm{g}$ in terms of average figures. Similarly, it was found out that the chard samples had the lowest B. cereus number of $2.6 \times 10^{2} \mathrm{CFU} / \mathrm{g}$ in this vegetable group (Table 5).

\section{Discussion}

Existence of Salmonella spp. and B. cereus were researched to determine the microbial quality of parsley, lettuce, spinach, turnip, carrot, chard, Brussels sprouts and radish offered in local bazaars in autumn, winter and spring. Although high level of bacteria detected in the vegetables does not imply existence of threat against human life, it can give us an idea about the sanitation conditions of the vegetables during the production and marketing process. Salmonella spp. infection is generally observed in areas which do not have a sewage system and poultry poop is mixed into the irrigation water. Salmonella 
spp. could not be detected in 89 vegetable samples analysed in our study. When the microbial load of 162 vegetable samples served raw in Brazil was analysed, Salmonella spp. was detected only in two wild chicory samples (1.2\%) (De Oliveira et al., 2011). Salmonella spp. was detected in $7.5 \%$ of 345 leaf vegetables put in sale in Spain (Ruiz et al., 1987). Considering the vegetables in terms of existence of $B$. cereus, the number of this bacterium was counted to be $<10$ in five samples analysed, and the $B$. cereus numbers varied in between $1.0 \times 10^{2}$ and $4.9 \times 10^{4} \mathrm{CFU} / \mathrm{g}$ in remaining 84 samples. Considering the existence of $B$. cereus in terms of the sampling seasons, spring yielded the highest figures in terms of both average and maximum values. Spring had the highest $B$. cereus number of $2.9 \times 10^{3} \mathrm{CFU} / \mathrm{g}$ in terms of average values. Enan et al. (2012), in their study examining the existence of $B$. cereus by seasons in meat, corn snacks and cheese stated that the highest and lowest values were obtained in summer and spring and autumn respectively. An increase in the $B$. cereus values of the products was observed under higher temperatures. Sampling was not carried out in summer in our study but spring was identified to yield higher values compared to autumn. This might have been caused by the fact that our autumn samples were collected in November when it was generally colder. Bartoszewicz et al. (2008) state that $B$. cereus existence was more frequent in fresh and heat-treated milk in spring and summer when it is hotter than autumn and winter and this supports our suggestion. Autumn is the season when all vegetable samples can be analyses. It was found out by examining the $B$. cereus numbers of vegetable samples of eight vegetable types that lettuce yielded the highest value of $8.2 \times 10^{2} \mathrm{CFU} / \mathrm{g}$ and it was followed by carrot and turnip with an average number of $4.8 \times 10^{2} \mathrm{CFU} / \mathrm{g}$. It was identified that parsley had the lowest value of $1.0 \times 10^{3}$ $\mathrm{CFU} / \mathrm{g}$. We believe that extreme values observed for lettuce and parsley are related to leaf structure and leaf layout of the vegetables. Hussain et al. (2019) mentioned that both substrate and cell surface composition might affect the bonding behavior. Kumar and Anand (1998) stated that cell surface properties such as adhesion proteins, capsules, surface load, flagella and pilus were important factors for active bonding of bacteria cells to substrate. In this vein, Elhariry (2011) set forth that lettuce and cabbage differed with regards to adherence surface and surface of lettuce supported adherence of spore and vegetative cells compared to cabbage. As a matter of course, hydrophobic $B$. cereus spores adhere and produce spores on hydrophobic structures (Kwon et al., 2017). In a study conducted by Rosenquist et al. (2005) in Denmark, 48.901 convenience food products including vegetables were analyzed in terms of existence of $B$. cereus and $B$. cereus numbers under $10^{3} \mathrm{CFU} / \mathrm{g}$, in $10^{3}-10^{4} \mathrm{CFU} / \mathrm{g}$ range and over $10^{4} \mathrm{CFU} / \mathrm{g}$ were detected in $98.7 \%, 0.7 \%$ and $0.5 \%$ of the samples respectively. Higher values were generally obtained in products containing fresh cucumber and tomato $(2.6 \%)$, heat-treated rice $(1.3 \%)$, cakes $(1.2 \%)$, and puddings containing milk and rice $(3.1 \%)$. In the same study, B. cereus number was measured to be under $10^{3}$ $\mathrm{CFU} / \mathrm{g}$ in $97.2 \%$ of vegetable and fruit products.

\section{Conclusion}

We find certain results interesting in this study in which the change of microbial quality in certain vegetables grown and marketed by local farmers by seasons. All vegetables were identified to be free of Salmonella spp. Detection of $B$. cereus in all but five samples indicate infection regarding this bacterium. Especially the B. cereus numbers of $10^{3}-10^{4}$ $\mathrm{CFU} / \mathrm{g}$ and over $10^{4} \mathrm{CFU} / \mathrm{g}$ detected in 18 and 2 lettuce samples respectively indicate that it is the vegetable with the highest infection rate. On the other hand, parsley and spinach (two samples and one sample respectively) are other vegetables with high infection rates due to their $B$. cereus values of $10^{3}-10^{4} \mathrm{CFU} / \mathrm{g}$. The stages of soil, harvesting, shipping and marketing should be analyzed in detail for the harvested products. Utmost importance should be attached to sanitation rules during both cultivation stage and harvesting and post-harvesting process of the products to prevent microbial infection. To reduce microbial infection rates, the containers used in the post-harvesting period as well as stands and shelves on which vegetables are put should be kept clean and made of material preventing adherence of bacteria. Clean water should be used for washing vegetables and humidifying them on the bench. It is recommended training farmers on sanitation and raising their awareness in order to ensure microbial quality during all processes from cultivation to the market.

\section{Declaration of Conflict of Interest}

The authors declare no conflict of interest. The founding sponsors had no role in the design of the study; in the collection, analyses, or interpretation of data; in the writing of the manuscript, and in the decision to publish the results.

\section{Authors' Contributions}

All authors contributed equally for the conception and writing of the manuscript. All authors critically revised the manuscript and approved of the final version.

\section{References}

Alissa EM, Ferns GA. 2017. Dietary fruits and vegetables and cardiovascular diseases risk. Critical Reviews in Food Science and Nutrition, 57(9): 1950-1962.

Avgoustaki DD, Xydis G. 2020. How energy innovation in indoor vertical farming can improve food security, sustainability, and food safety? Advances in Food Security and Sustainability, 5: 1-51.

Balali GI, Yar DD, Afua Dela VG, Adjei-Kusi P. 2020. Microbial contamination, an increasing threat to the consumption of fresh fruits and vegetables in today's World. Int J Microbiol, 22: 3029295. doi: 10.1155/2020/3029295.

Barminas JT, Charles M, Emmanuel D. 1998. Mineral composition of non-conventional leafy vegetables. Plant Foods for Human Nutrition, 53(1): 29-36.

Bartoszewicz M, Hansen BM, Swiecicka I. 2008. The members of the Bacillus cereus group are commonly present contaminants of fresh and heat-treated milk. Food Microbiology, 25(4): 588-596.

Baslam M, Garmendia I, Goicoechea N. 2011. Arbuscular mycorrhizal fungi (AMF) improved growth and nutritional quality of greenhouse-grown lettuce. Journal of Agricultural and Food Chemistry, 59(10): 5504-5515. 
Beuchat LR, Ryu JH. 1997. Produce handling and processing practices. Emerging Infectious Diseases, 3(4): 459-465.

Bergwerff AA, Debast SB. 2021. Modernization of control of pathogenic micro-organisms in the food-chain requires a durable role for immunoaffinity-based detection methodology-A review. Foods, 10(4): 832. doi: 10.3390/foods 10040832 .

D'Aoust JY, Maurer J. 2007. Salmonella species. In Food Microbiology: Fundamentals and Frontiers, Third Edition (pp. 187-236). USA: American Society of Microbiology.

De Oliveira MA, De Souza VM, Bergamini AMM, De Martinis ECP. 2011. Microbiological quality of ready-to-eat minimally processed vegetables consumed in Brazil. Food Control, 22(8):1400-1403.

Elhariry HM. 2011. Attachment strength and biofilm forming ability of Bacillus cereus on green-leafy vegetables: cabbage and lettuce. Food Microbiology, 28(7): 1266-1274.

Enan G, Awny N, Abou Zeid AA, Abdou MA. 2012. Incidence and virulence of Bacillus cereus isolated from Egyptian foods during four seasons. African Journal of Microbiology Research, 6(22): 4816-4824.

Gil MI, Selma MV, Suslow T, Jacxsens L, Uyttendaele M, Allende A. 2015. Pre-and postharvest preventive measures and intervention strategies to control microbial food safety hazards of fresh leafy vegetables. Critical Reviews in Food Science and Nutrition, 55(4): 453-468.

Giray H, Soysal A. 2007. Food safety and related laws in Turkey. TAF Preventive Medicine Bulletin, 6(6): 485-490.

Hussain MS, Kwon M, Park EJ, Seheli K, Huque R, Oh DH. 2019. Disinfection of Bacillus cereus biofilms on leafy green vegetables with slightly acidic electrolyzed water, ultrasound and mild heat. LWT, 116:108582.

Ignarro LJ, Balestrieri ML, Napoli C. 2007. Nutrition, physical activity, and cardiovascular disease: an update. Cardiovascular Research, 73(2): 326-340.

Kenney LJ. 2019. The role of acid stress in Salmonella pathogenesis. Current Opinion in Microbiology, 47: 45-51.

Kim JB, Jeong HR, Park YB, Kim JM, Oh DH. 2010. Food poisoning associated with emetic-type of Bacillus cereus in Korea. Foodborne Pathogens and Disease, 7(5): 555-563.

Kumar CG, Anand SK. 1998. Significance of microbial biofilms in food industry: a review. International Journal of Food Microbiology, 42(1-2): 9-27.

Kumari S, Sarkar PK. 2016. Bacillus cereus hazard and control in industrial dairy processing environment. Food Control, 69: 20-29.

Kwon M, Hussain MS, Oh DH. 2017. Biofilm formation of Bacillus cereus under food-processing-related conditions. Food Science and Biotechnology, 26(4): 1103-1111.

Mie A, Andersen HR, Gunnarsson S, Kahl J, Kesse-Guyot E, Rembiałkowska E, Quaglio G, Grandjean P. 2017. Human health implications of organic food and organic agriculture: a comprehensive review. Environ Health, 16(1):111. doi: 10.1186/s12940-017-0315-4.

Mohammed FS, Günal S, Pehlivan M, Doğan M, Sevindik M, Akgül H. 2020. Phenolic content, antioxidant and antimicrobial potential of endemic Ferulago platycarpa. Gazi University Journal of Science, 33(4): 670-677.
National Standards Authority of Turkey 2009. TS EN ISO 7932Microbiology-General Guidance For the Enumeration of Bacillus cereus-Colony Count Technique at $30^{\circ} \mathrm{C}$ (Made use of EN ISO 7932: 2004).

National Standards Authority of Turkey 2020. Microbiology of the food chain - Horizontal method for the detection, enumeration and serotyping of Salmonella - Part 1: Detection of Salmonella spp. - Amendment 1 Broader range of incubation temperatures, amendment to the status of Annex $\mathrm{D}$, and correction of the composition of MSRV and SC. (Made use of EN ISO 6579-1:2017/A1:2020).

Organji RS, Abulreesh HH, Elbanna K, Osman GEH, Khider M. 2015. Occurrence and characterization of toxigenic Bacillus cereus in food and infant feces. Asian Pacific Journal of Tropical Biomedicine, 5(7): 515-520.

Pehlivan M, Mohammed FS, Şabik AE, Kına E, Dogan M, Yumrutaş Ö, Sevindik M. 2021. Some Biological activities of ethanol extract of Marrubium globosum. Turkish Journal of Agriculture-Food Science and Technology, 9(6): 1129-1132.

Pekşen E, Artık C. 2005. Antibesinsel maddeler ve yemeklik tane baklagillerin besleyici değerleri, OMÜ Zir. Fak. Dergisi, 20(2): 110-120.

Ronto R, Wu JH, Singh GM. 2018. The global nutrition transition: trends, disease burdens and policy interventions. Public Health Nutrition, 21(12): 2267-2270.

Rosenquist H, Smidt L, Andersen SR, Jensen GB, Wilcks A. 2005. Occurrence and significance of Bacillus cereus and Bacillus thuringiensis in ready-to-eat food. FEMS Microbiology Letters, 250(1): 129-136.

Ruiz BGV, Vargas RG, Garcia-Villanova R. 1987. Contamination on fresh vegetables during cultivation and marketing. International Journal of Food Microbiology, 4(4): 285-291.

Sevindik M, Akgul H, Pehlivan M, Selamoglu Z. 2017. Determination of therapeutic potential of Mentha longifolia ssp. longifolia. Fresen Environ Bull, 26(7): 4757-4763.

Steinmetz KA, Potter JD. 1996. Vegetables, fruit, and cancer prevention: a review. J Am Diet Assoc, 96(10): 1027-1039. doi: 10.1016/S0002-8223(96)00273-8.

Ugur A, Gok Y, Ugur HG. 2014. Impact of socio-cultural and economic factors on vegetable consumption behaviours: case of Giresun province, Turkey. Food Science and Technology, 34(4): 688-693.

Valero M, Fernandez PS, Salmeron MC. 2003. Influence of pH and temperature on growth of Bacillus cereus in vegetable substrates. International Journal of Food Microbiology, 82(1): 71-79.

Yen ST, Tan AKG. 2012. Who are eating and not eating fruits and vegetables in Malaysia?. Int J Public Health, 57: 945-951. https://doi.org/10.1007/s00038-012-0343-3

Yücel E. 2020. Salmonella enfeksiyonları, tanı ve tedavisi. Klinik Tip Pediatri Dergisi, 12(3): 133-139.

Zhao T, Zhao P, Doyle MP. 2009. Inactivation of Salmonella and Escherichia coli O157: H7 on lettuce and poultry skin by combinations of levulinic acid and sodium dodecyl sulfate. Journal of Food Protection, 72(5): 928-936. 